\title{
前立腺結核, 統計及ビ手惦例
}

\author{
(前汒腺絬核ノ研觉 1.) \\ 〔泌尿生列器結核ノ研究 第 3 回]
}

T. Itikawa und K.Kiniura: Über Statistik der

Prostatatuberkulose und ihre Opcrationsfalle.

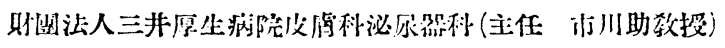

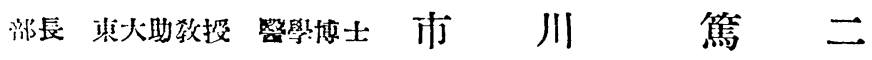

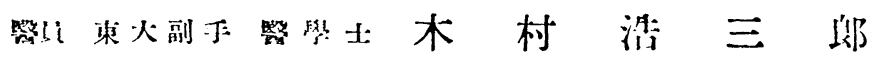

\section{I. 頻度}

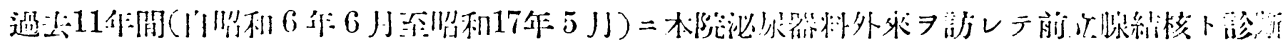

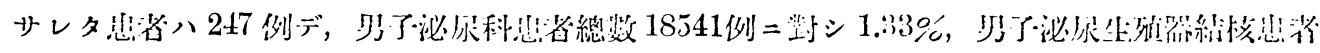

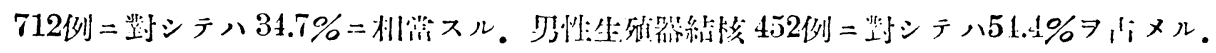

\section{II. 年齡}

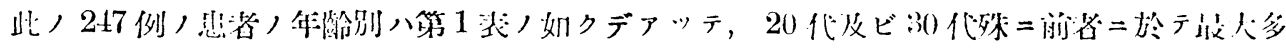
数 $\ni ! \vdots \times ル 。$

\section{III. 既 往 症}

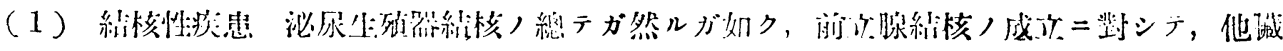

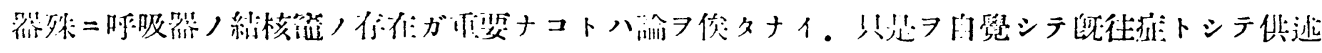

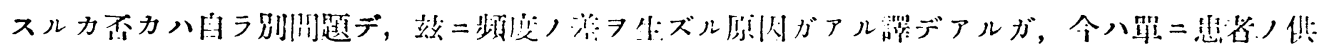
述二從ツテ記找スルニ业メル。

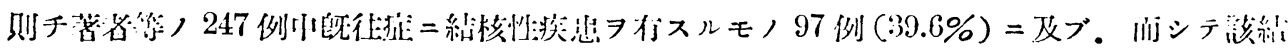

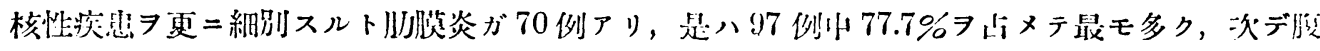

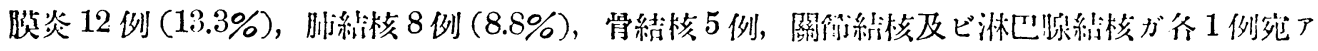
r.

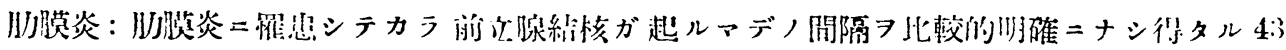

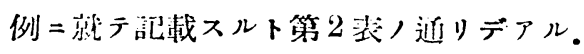

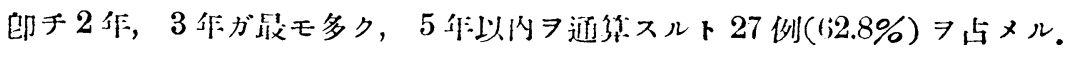

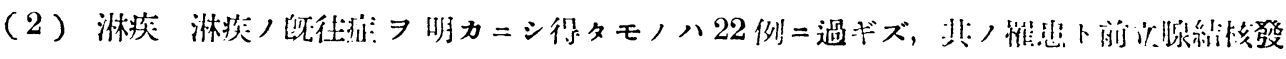
生汽ノ誾隔八第 3 表二示ス近リデアル。 


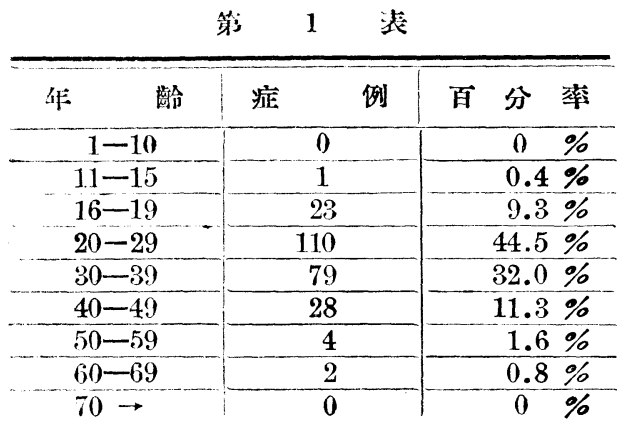

第 $2 \quad$ 表

\begin{tabular}{|c|c|c|}
\hline 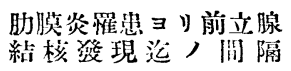 & 例 & 數 \\
\hline 年: & 3 & \\
\hline 年 & 7 & \\
\hline 作 & 7 & \\
\hline 作 & 5 & \\
\hline 年 & 5 & \\
\hline 年 & 4 & \\
\hline 年 & 3 & \\
\hline 年 & 2 & \\
\hline 9 年 & 0 & \\
\hline 10 牛以 上 & 7 & \\
\hline
\end{tabular}

第 3 表

\begin{tabular}{|c|c|c|c|c|}
\hline \multicolumn{2}{|c|}{ [ii] } & 隔 & \multirow{2}{*}{$\frac{\text { 症 }}{1}$} & \multirow{2}{*}{ 例 } \\
\hline 1 & 訨: & 以 & & \\
\hline 3 & 洤三 & [iii] & 5 & \\
\hline 4 & 年 & [㳉] & 2 & \\
\hline 5 & 年 & 間 & 5 & \\
\hline 6 & 年 & 間 & 1 & \\
\hline 7 & 年 & 間 & 2 & \\
\hline 8 & 年 & 間 & 1 & \\
\hline 9 & 年 & 間 & 0 & \\
\hline 10 & 年 & 以 $\mathrm{E}$ & 5 & \\
\hline & 訫 & & 22 & \\
\hline
\end{tabular}

第 4 表

\begin{tabular}{|c|c|c|}
\hline 絬 核 䆗 人部 位 & 症例數 & $\begin{array}{l}173 \text { 例二 } \\
\text { 對 ス } \\
\text { 百分茶 }\end{array}$ \\
\hline 前立腺＋留 臟 & 58 & $33.5 \%$ \\
\hline 前立腺十副器丸 & 35 & $20.2 \%$ \\
\hline 前立腺十副罢丸十督 贜 & 43 & $24.9 \%$ \\
\hline 前立腺十副案丸十精 壱 & 15 & $8.7 \%$ \\
\hline 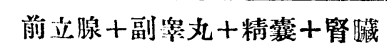 & 22 & $12.7 \%$ \\
\hline
\end{tabular}

\section{IV. 合 併症}

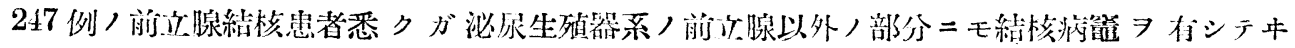
ル。郎チ合併掠トシテノ泌疗生殖器結核ハ $100 \%$ フ占メル。

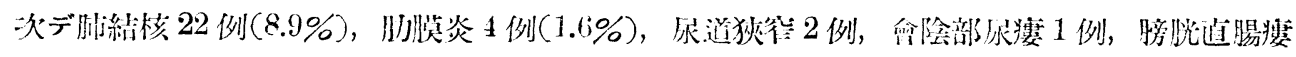

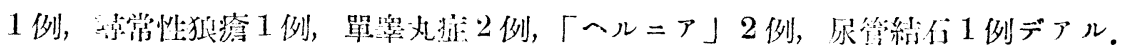

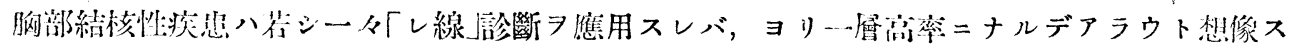

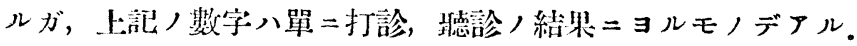

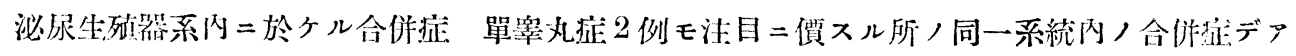

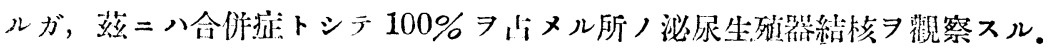

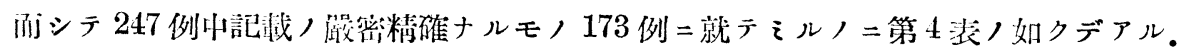

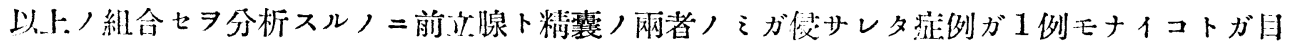

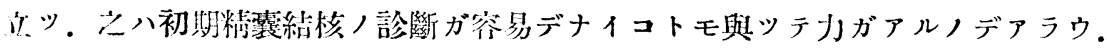

\section{$\nabla$. 症狀}

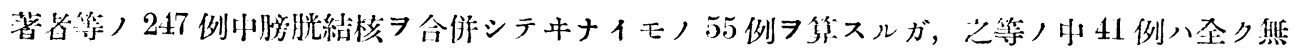

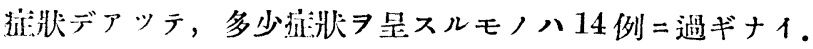

此ノ14 例 


\begin{tabular}{|c|c|c|c|c|}
\hline 總 數 & 大 & $\forall$ & 例 數 & 百分率 \\
\hline \multirow{3}{*}{171} & \multicolumn{2}{|c|}{ 菇明二坦大 } & 21 & $12.2 \%$ \\
\hline & 通 倄 & 大 & 112 & $65.5 \%$ \\
\hline & 縮 & 小 & 38 & $22.3 \%$ \\
\hline
\end{tabular}

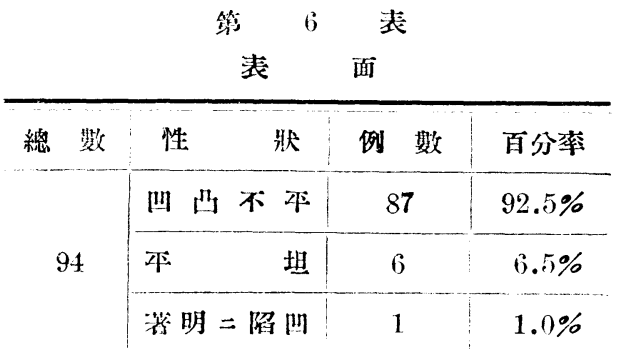

\begin{tabular}{|c|c|c|c|}
\hline 總 數 & 硬 & 例 数 & 百分率 \\
\hline \multirow{2}{*}{201} & $\begin{array}{l}\text { 硬靱部 } \\
\text { 正常部トアリ }\end{array}$ & 196 & $97.5 \%$ \\
\hline & 波動 ア & 5 & $2.5 \%$ \\
\hline
\end{tabular}

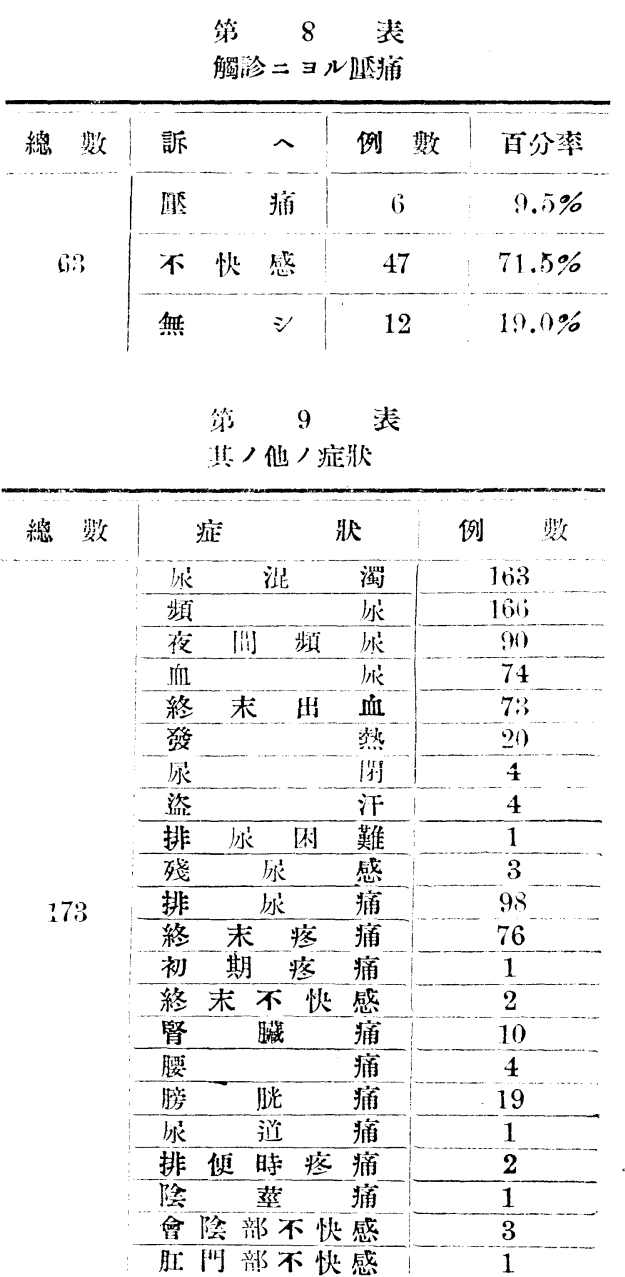




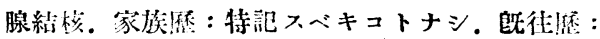

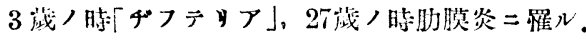

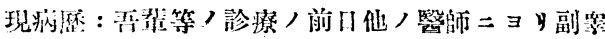
丸睡脹キ指摘サレタモノデ何等白學的莎痛ハナ 1. 现症：體胳中等大，策表比較的可良，胸腹部

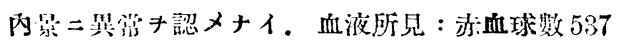

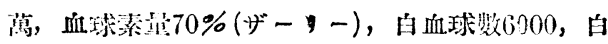

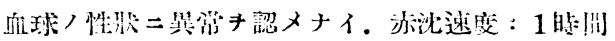

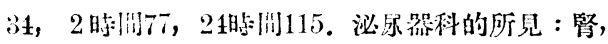

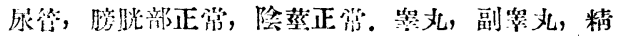

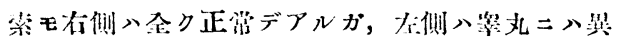

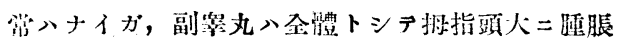

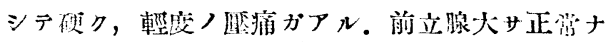

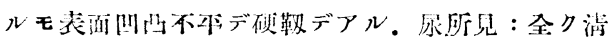

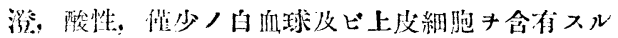

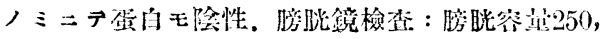

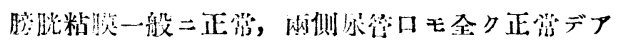

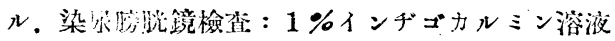

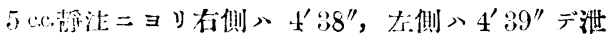

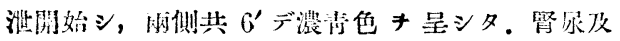

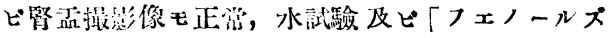
ルフォンフタタイン」ニヨル總腎機能檢枯ノ結喿 モ亦全ク正箸デアル。

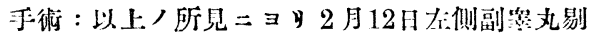

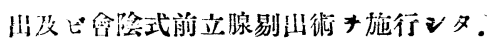

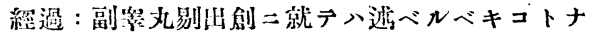

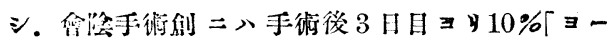
ドフォルムグリセリン」キ注入シタ. 手術後 20 日

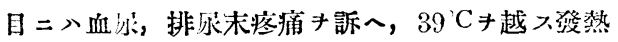

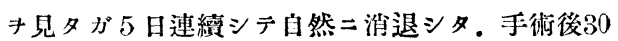
月目填二八手術創䔄シク縮小シ，分泌娍少シタ が全治二八至ラナイノデ深部療法キ施行シ, 手維 後的 2 月㳇ノ 4 月初勾二八完全二步行シテ退院シ タ. 梌後通院シテ細イ瘦孔全治二カメタガ中途履 療シタ. 術後第70日目 (4月23日)二撮影シタ尿道

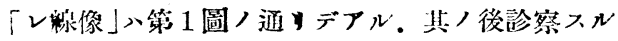

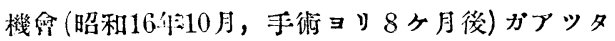

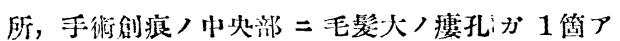
タ，僅少ノ浆液性分泌物がミレルノミデ一般状
態極メテ良好デアッタ。但シ性忿少ク勃爬ハ不充 分デフルト述べタ。

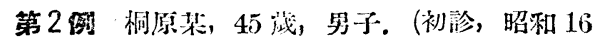
作: 2 月 10 日)。家族糜：特訅スベキコトナシ。既

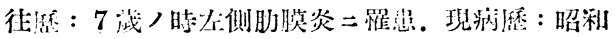
14年9月月初メテ血尿ガアッタ. 少ノ後!ケ月二

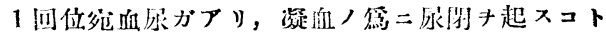

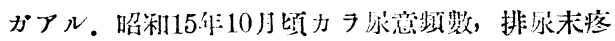

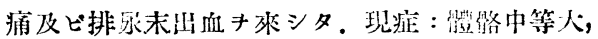

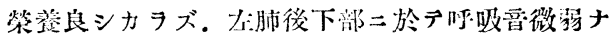
ル以外胸部二罢落ナシ。血液所見：赤血球558萬,

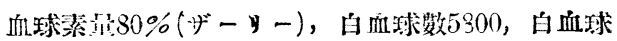

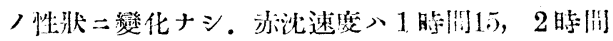

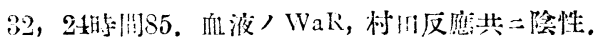

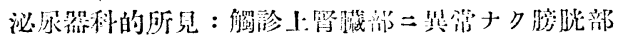

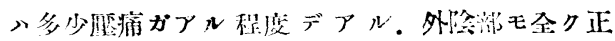

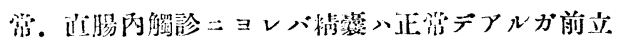

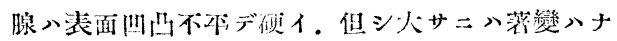

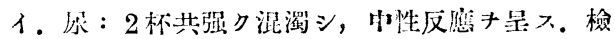
鏡二ョリ多数/日血球卜絬核菌站二少許/上皮細

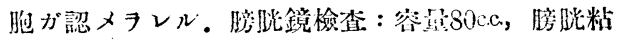

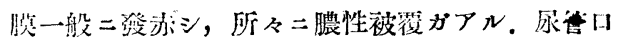

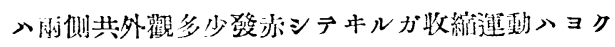

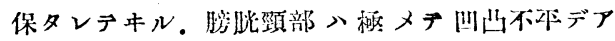
ル. 染㽷膀脱鏡检查：石侧 $4^{\prime} 45^{\prime \prime}$ デ排泄開始シ，

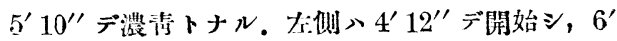

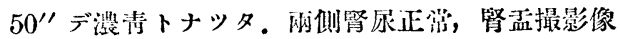
正常. 總䁂機能 ハ「フェノールプフォンフタタィ ン」/排泄入 2 晣间合䚵 $45 \%$ デ良好卜ハイヘナイ

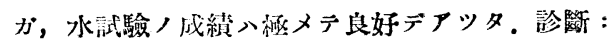

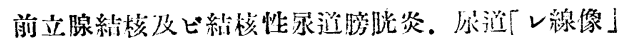
ハ第 2 圖ノ通りデル.

手術：會陰式前立腺剔出術 $\neq$ 施行(昭和16留: 2

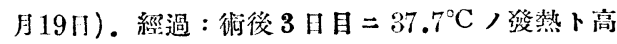
度ノ血㲾トキ胃タガ 2 日デ下熱シ，血疗无漸次輕

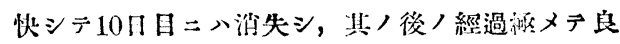
好デ于手術後 1 万月日二再ビ疗道撮影法キ行ッテ第 3 圖キ得，19日日二八全治退院シタ。 
市川・木村論文附圖

筷 1 圖

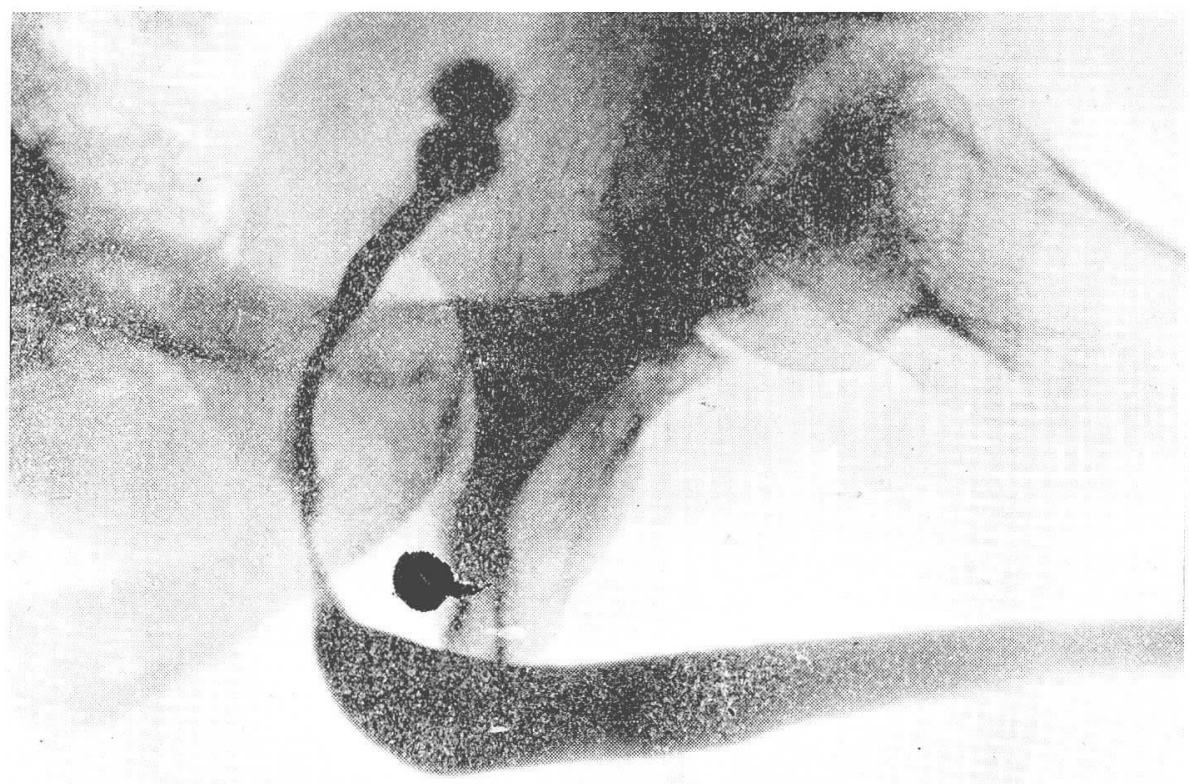

第 2 滴

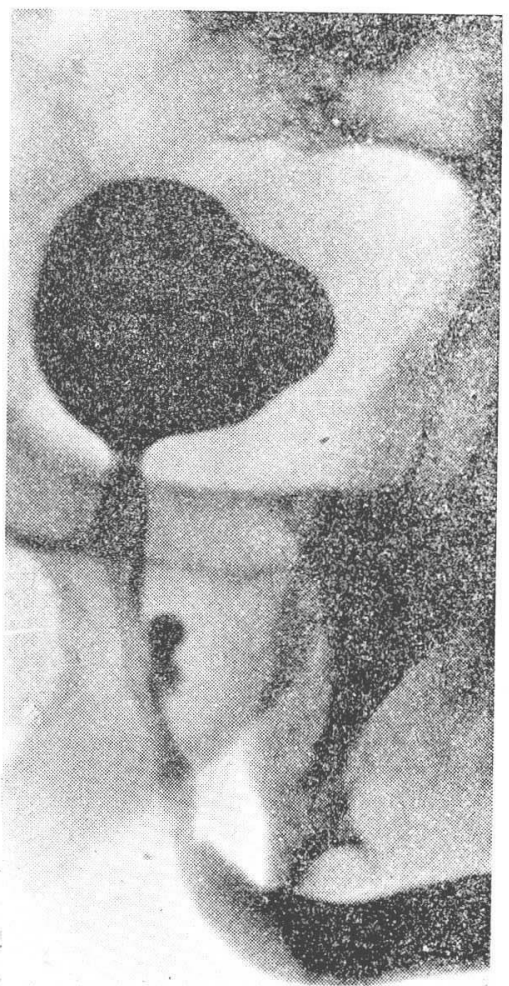

䈞 3 圖

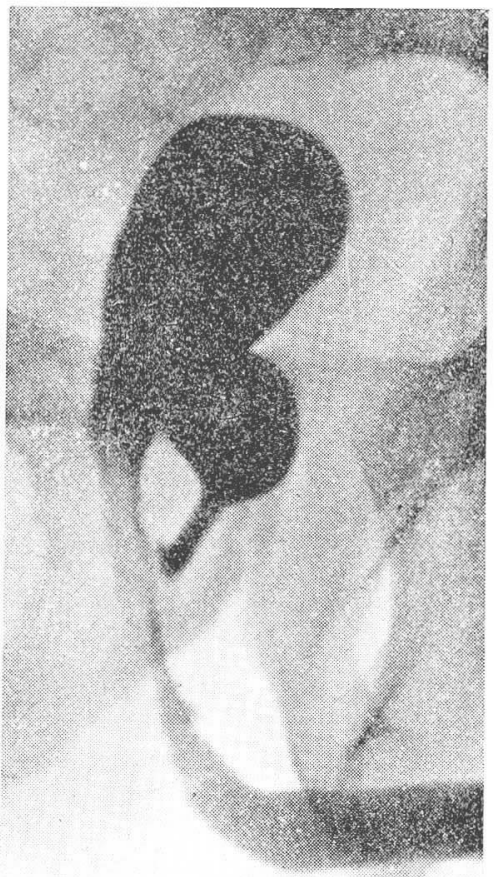

